\title{
Online Marketing Strategy Analysis of PT. Bagus Trans Wisata
}

\author{
Kevin Benedict Lesmana*, Rustono Farady Marta, Sugeng Wahjudi \\ Master of Communication Science, Postgraduate Program, \\ Universitas Bunda Mulia, Indonesia \\ *Corresponding Author: kevinbenedict0702@gmail.com
}

DOI: https://doi.org/10.24922/eot.v8i1.70278

\section{Article Info \\ Submitted \\ February $2^{\text {nd }} 2021$ \\ Accepted \\ March $18^{\text {th }} 2021$ \\ Published \\ March $31^{\text {th }} 2021$}

\begin{abstract}
The tourism industry is one of the largest industries in the world, including Indonesia. So it is said that this industry has a considerable influence, so that it can be ascertained that this is an opportunity for a business. The large number of existing social media makes marketers have to see an appropriate and broad target. Based on this, marketers must be fully prepared with the selection of media, certain efforts and ways to attract consumers. PT. Bagus Trans Wisata has used new media as a channel in promoting its travel products. One of the new media used, namely Facebook, the use of this new media is one proof of the success of a well-known company name throughout Indonesia. New media is a new form of social media used by the public, considering that conventional media is less effective in conveying mass messages. This paper aims to examine marketing strategies through social media at PT. Bagus Trans Wisata. This research uses descriptive research with a qualitative approach which aims to identify, describe and explain the actual situation related to the marketing strategy undertaken by the service company PT. Bagus Trans Wisata Tour \& Travel Jakarta.
\end{abstract}

Keywords: online, marketing, tourism, travel

\section{INTRODUCTION}

Tourism is one of the areas favored by the Indonesian government for earning foreign exchange. Tourism as a form of development encouragement plays a role as a source of foreign exchange income and also contributes a lot to other fields. Until now, the tourism sector is still positioned as the leading sector for the Indonesian economy. (Suryani, 2017).

Indonesia has enormous tourism potential and it is hoped that this will be able to become one of the strengths of reliable infrastructure development. In this connec- tion, the government always tries to pay attention to the development of tourism. The tourism industry is an industry that includes various roles, professions, and jobs in its continuity. All of them have their respective roles to make the tourism industry run well. (Setiawan, 2019).

Lately there have been many community-based companies that have initiated "open trips". These various companies have provided new nuances in their types of travel since 2016. This causes tourists to switch because the price offered is quite skewed and adds to the scope of new friends because the characters who follow this trip 
come from any group with locations of residence in various cities in Indonesia. This type of travel is popular with most people, especially the millennial generation who want to have a new network of friends and a minimal budget. Usually companies have many travel packages on each of the dates on the holidays. (Brahmanto, 2015).

The destinations offered are al so diverse, unique, and rarely owned by travel agents in general. Open trip travel agencies market their travel products through online media, either through Instagram, Facebook, or even the newest platform for millennials, TikTok. This open trip travel agency also often invites several artists and celebrities to attract consumers to be interested in traveling with this company. The company, which has only been running for 4 years, promotes its travel products only through online social media, namely Facebook. (Atiko, et al, 2016).

Facebook is one of the most widely used social networks by Indonesians, so it is not surprising that Facebook can be a business opportunity as well as a very potential product marketing tool. Facebook provides a place to meet and communicate between a member and other members. With the increasing number of members who gather, Facebook then offers ad spots to members in marketing or promoting products. (Watie, 2016).

Every activity at PT. Bagus Trans Wisata is well organized into a tour package and marketed to individual and group tourists via online media. The target market segmentation is Indonesian citizens who wish to travel abroad on a sloping budget. No wonder there are many millennials who join this travel program. (Aryani, 2017).

Consumers or potential tourists do not even need to come to the company, but can access via Facebook by opening a site that is already available or can directly contact via WhatsApp to the intended number. Online media was chosen because the rapid development of information technology affects the lifestyle of today's consumers. Similar to the research raised by Ariani Putri (2010) entitled "The Role of Online Media in Marketing of Tourism Products at the Nusa Jaya Travel Agency, Bandung," in her research, the author said that promotion on online media can facilitate consumers and be more efficient for companies. (Sari, et al., 2016).

\section{METHODS}

This study uses a descriptive research type with a qualitative approach that aims to identify, describe and explain the actual situation related to the marketing strategy undertaken by the service company PT. Bagus Trans Wisata. The research location was determined using the purposive area method. Data collection methods used by researchers include in-depth interviews, observation methods and documentation techniques. In addition, the primary data source is a data sourced from PT. Bagus Trans Wisata and other data is secondary data which is data through literature in the same direction as this research. The analysis technique used is the SWOT analysis technique which focuses on the marketing strategy of PT. Bagus Trans Wisata in attracting tourists to use PT. Bagus Trans Wisata.

\section{RESULTS AND DISCUSSION}

Marketing strategies carried out through online media at PT. Bagus Trans Wisata is a strategy to make it easier for potential tourists to access the tour packages they want. The influence of online media also affects segmenting, targeting and positioning. The market share of this company is mostly seniors and also aged 40 years and over who already have a lot of free time, but it is undeniable also with other circles. (Salam, et al., 2019). 
In marketing the package, PT. Ba- a published rate according to the price gigus Trans Wisata is included in the BTC ven on Facebook or via WhatsApp. Current or Business to Customer category, namely technological developments are directly tourists who buy tour packages directly to proportional to the rapid growth of travel PT. Bagus Trans Wisata will be subject to agencies in Indonesia. (Budiasih, 2019).

Table 1. Matrik SWOT Analysis Marketing of Tour Packages through Online Media at PT. Bagus Trans Wisata

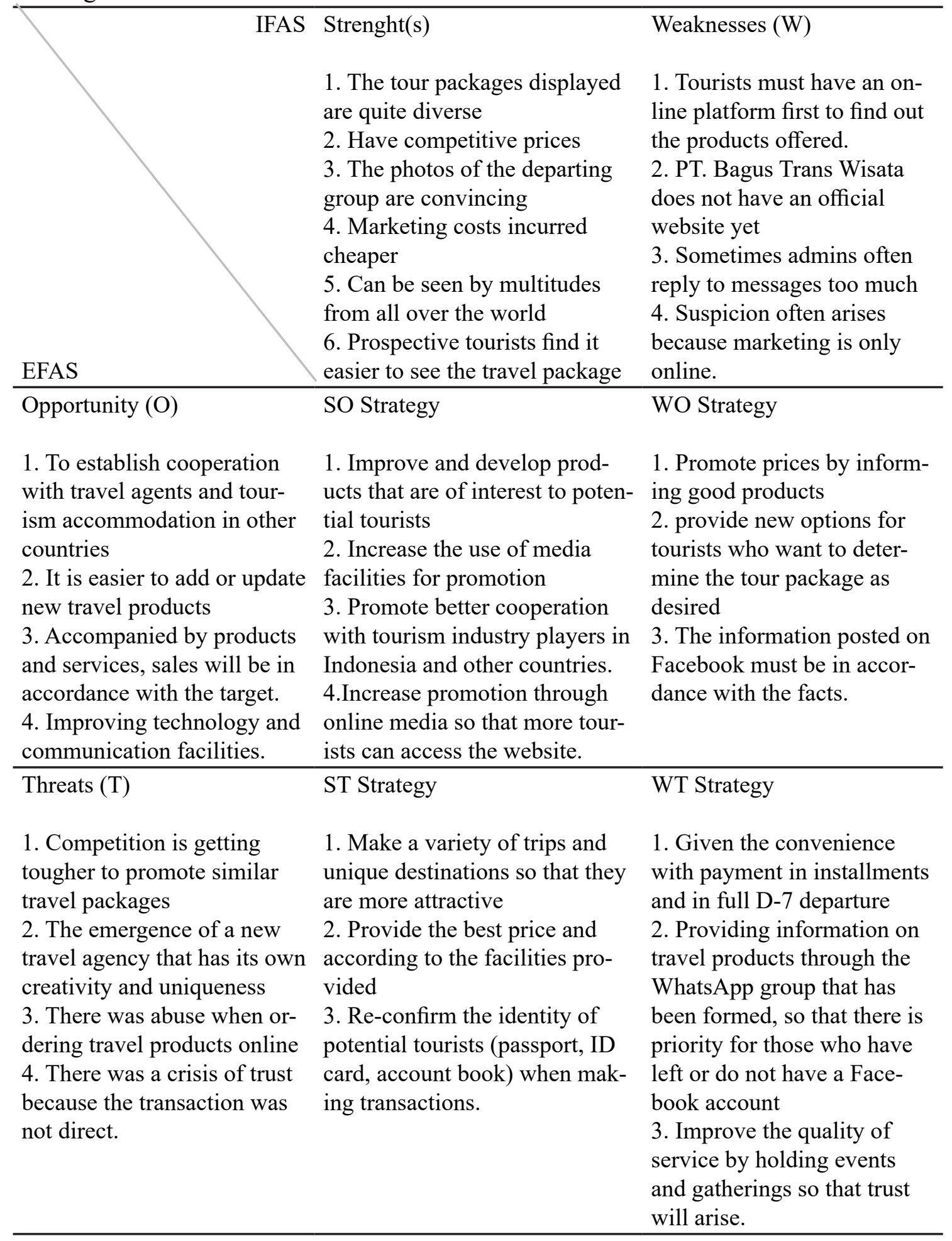


Therefore, facing this, PT. Bagus Trans Wisata continues to improve its strategy to be able to compete in current conditions. Discussing these problems, a SWOT analysis was obtained regarding the strengths, weaknesses, opportunities, and threats in marketing travel products online at PT. Bagus Trans Wisata which can be seen in Table 1.

Based on the research results Table 1, it can be described that the marketing of the tour packages of PT. Bagus Trans Wisata is right to choose online media as a promotional and marketing medium. Judging from the SWOT analysis where each strategy shows and increases the excellence in marketing the tour packages of PT. Bagus Trans Wisata by minimizing and eliminating weaknesses and threats.

The right strategy is used for marketing tour packages through online media at PT. Bagus Trans Wisata is to take advantage of travel packages that are diverse, unique, and attractive package packages to increase tourist interest and cheap package prices must be accompanied by product quality so that sales are on target, provide accurate information on Facebook so there is no crisis of tourist trust, as well as using an internet connection system that has good quality, in order to minimize the occurrence of system errors.

And currently the company PT. Bagus Trans Wisata uses online media to increase the level of tourist visits, but marketing through printed media such as brochures and other electronic media has not been forgotten. Because it would be better needed when doing promotions in places that are visited by many people, such as holding exhibitions.

\section{CONCLUSION}

The results show that Facebook does not only play a role as a promotional medium in the development of a travel agency, but also as a medium for communicating with potential customers. In addition, the use of social media (Facebook) in developing travel products can change from being unknown to being known by many people. This has a very positive impact or influence on sales results in a travel agency company.

On the other hand, current technological developments are in line with the rapid growth of travel agents in Indonesia which is increasingly mushrooming and competition is fierce. PT. Bagus Trans Wisata certainly continues to improve its strategy to stay afloat and compete with other travel agents. Discussing these problems, a SWOT analysis was obtained regarding the strengths, weaknesses, opportunities and threats in marketing tour packages through online media at PT. Bagus Trans Wisata Based on the results of the research above, it can be said that it is right to choose online media as a media for promotion and marketing of tour packages. Because it has been proven in the SWOT analysis it shows that many internal factors have a positive impact on the company. The advantages of each strategy that come from within the company must be continuously improved which aims to further minimize the weaknesses and threats of competitors. Standing in a service company, PT. Bagus Trans Wisata must continue to develop new strategies in order to survive in the tourism industry and be able to compete with companies, especially travel agents.

\section{REFERENCES}

Aryani, N. L. P. N. (2019). Analisis Segmentasi Pasar Dalam Menentukkan Pasar Sasaran Utama Pada PT. Pacto Bali Travel. Jurnal Penelitian Agama Hindu, 1(1) pp. 105-111.

Atiko, G., Sudrajat, R. H., and Nasionalita, K. (2016). Analisis Strategi Promosi Pariwisata Melalui Media Sosial Oleh Kementrian Pariwisata Ri (Studi e-ISSN 2407-392X. p-ISSN 2541-0857 
Deskriptif Pada Akun Instagram@ Indtravel). eProceedings of Management, 3(2).

Budiasih, M. (2019). Pariwisata Spiritual di Bali. Pariwisata Budaya: Jurnal Ilmiah Agama dan Budaya, 2(1) pp.7080.

Brahmanto, E. (2015). Magnet Paket Wisata Dalam Menarik Kunjungan Wisatawan Asing Berkunjung Ke Yogyakarta. Media Wisata, 13(2).

Setiawan, I. (2015). Potensi Destinasi Wisata di Indonesia Menuju Kemandirian Ekonomi, Prosiding Seminar Nasional Multi Disiplin Ilmu\&Call For Papers Unisbank (Sendi_U), 53(9), Pp. 1689-1699.

Sari, A. P., Negara, I. M. K., \& Suardana, I. W. (2016). Strategi Pemasaran Paket
Wisata Melalui Media Online Di Truly Asia Tour and Travel. Jurnal IPTA (Industri Perjalanan Wisata), 4(1), pp. 74-78.

Salam, H. I., Widodo, J., \& Zulianto, M. (2019). Strategi Pemasaran Pada Pt Nuansa Wisata Prima Nusantara Tour \& Travel Jember. Jurnal Pendidikan Ekonomi: Jurnal Ilmiah Ilmu Pendidikan, Ilmu Ekonomi Dan Ilmu Sosial, 13(1), pp. 66-71.

Suryani, A. I. (2017). Strategi Pengembangan Pariwisata Lokal. Jurnal Spasial: Penelitian, Terapan Ilmu Geografi, dan Pendidikan Geografi, 3(1).

Watie, E. D. S. (2016). Komunikasi dan media sosial (communications and social media). Jurnal The Messenger, 3(2), pp. 69-74. 